\title{
Exploration on the Education Mode of College Student Associations Under the Support of Professional projects
}

\author{
Li Yue
}

\author{
Guangzhou Huashang Vocational College, Guangzhou511300, China. \\ Email:15989280129@126.com
}

\begin{abstract}
The community of colleges and universities is a non-profit organization association for the self-initiation, selfmanagement and self-education of the university students. It can enrich the life of students by organizing the internal activities and the activities of the community, and help the students to develop their interests, learn knowledge and develop their abilities. Under the support of the professional project, the college students' association education mode has the characteristics of strong free practice and good innovation. In order to help that students get out of the society, to understand and understand the society and to improve the ability of college students to adapt to the future in the future. The school has institutionalized management to the community, and under the support of the professional project, the colleges and universities carry out the education of professional college students' associations through social practice, voluntary service, innovation and entrepreneurship. The cultivation and practice of the core values are integrated into all aspects of the college students' learning and life, the effectiveness of the value education is improved, and the time nature of the students' association education under the support of the professional project is promoted.
\end{abstract}

Keywords: professional project support, university, student association, education mode

\section{Introduction}

College community organizations can enrich campus culture, strengthen students' ideological and political education and quality education imperceptibly, and play the function of socialized training for students' employment, innovation and entrepreneurship. Marxist theory of allround development of human beings holds that practice is the fundamental way to realize the all-round development of human beings. As one of the main ways of ideological and political education in colleges and universities, more and more attention has been paid to the education of college student associations supported by professional projects. General Secretary Xi stressed at the National Conference on ideological and political Affairs in Colleges and Universities: "We should attach importance to the education of college student associations with the support of professional projects, persist in the combination of education with productive labor and social practice, and extensively carry out all kinds of social practices." The report of the 19th CPC National Congress pointed out that socialism with Chinese characteristics has entered a new era. In the face of the new background of the times, the educational work of college student associations under the support of professional projects is facing new opportunities and challenges. Improving the times of college student associations' education under the support of professional projects is related to the effectiveness and effect of ideological and political education in colleges and universities ${ }^{[1]}$.

General Secretary Xi Jinping pointed out: in order to do a good job in guiding young people's thinking, the Communist Youth League must stand on the commanding point of ideals and beliefs, and only with ideological and spiritual attraction and cohesion can it be internally strong and lasting. It is necessary to help the broad masses of young people to set up lofty ideals, arm young people with scientific theory, enlighten young people with historical eyes, inspire young people with great goals, and inspire young people with a bright future. As the most active place for young people, college associations cover the largest area of students. with the development of the new era and the importance attached to quality education in colleges and universities, associations have become the main position of the second classroom of the school and the window for students to give full play to their talents. However, with the rapid development of Internet and information technology, the development of associations increasingly shows that the brand activities are insufficient, the connotation construction is not enough, and the lack of ideological guidance, so how to solve the problems in the development of associations is particularly important.

\section{Background of the times for college student associations to educate people with the support of professional projects}

The work of college student association education is carried out under the background of the times, and the object of the work of college student association education is the young college student with the characteristics of the times ${ }^{[2]}$.

\subsection{New features of the new era}

From the point of view of the international situation, the international situation is complicated, peace, development, win-win and cooperation are still the themes of the times. Today's world presents the characteristics of 
multipolarization, informatization, globalization and so on. At the same time, trade protectionism, hegemonism and power politics in developed countries still exist, and the international situation is unstable. From the point of view of the domestic situation, the fundamentals of China's economy have not changed for a long time, and the society as a whole is harmonious and stable. At the same time, China's economic and social transformation has accelerated and economic development has entered the new normal ${ }^{[3]}$. At present, China's reform is in the stage of tackling key problems. With the development and change of the social situation, some outstanding contradictions and problems faced by the development of our country for a long time have not yet been fundamentally solved, and some new situations and new problems have emerged, and the main contradictions of the society have changed. With the rapid development of modern science and technology and communication technology, people's personalized differences are more obvious, showing a variety of interests ${ }^{[4]}$.

\subsection{Characteristics of contemporary college students}

Contemporary young college students grew up in the new era, most of them after "95", showing obvious characteristics of the group characteristics of the times. From the external environment, their growth environment is superior, the material conditions are relatively rich; with the rapid development of scientific and technological innovation, they accept a large amount of information; in the family structure, most of the students are "4-2-1" or "42-2" inverted pyramid, the only child and the second child occupy the majority, therefore, they get more attention from their parents, and family education is more favored. At the same time, the social competition faced by contemporary college students is very fierce and the pressure is great. These external environments have created some common group characteristics of college students ${ }^{[5]}$.

From the characteristics of contemporary college students, they have a strong enterprising spirit and competitive consciousness, strong desire to express, individual consciousness tends to strengthen, collective consciousness desalination, there is a certain utilitarian tendency. At the same time, their sense of responsibility is not strong, practical ability and labor ability have been degraded, and their psychology is fragile. Under the influence of the popularization and development of modern network technology, college students generally rely strongly on the network.

\section{PRESENT SITUATION OF THE EDUCATIONOF COLLEGESTUDENT ASSOCIATIONSSUPPORTED BYPROFESSIONALPROJECTS}

\subsection{Improvement of cultivating people by Student Associations in Colleges and Universities with the support of Professional projects}

Since the new era, the professional project has supported the improvement of the education of the college students' associations, and has achieved remarkable results. First, the support of the professional project is more and more important to the education of college students' associations. With the development of the times and the improvement of the quality of the new talents, the national, the society and the colleges and universities have paid more and more attention to the education of the college students' associations with the support of the professional projects, and have given a lot of support in the aspects of policy, personnel, funds and so on. In 2012, The Ministry of Education and other departments have issued a number of suggestions on the further strengthening of the education of the students' associations under the support of the professional project. In 2016, the new revision of the "Regulations for the Management of the Students in the General Institutions of Higher Learning" is defined in the "The school should encourage, support and guide the students to take part in the social practice and innovation and start-up activities, and can set up an innovative startup file and set up an innovative start-up credit.". In 2017, the Ministry of Education released the Outline of the Implementation of the Quality of Ideological and Political Work of Colleges and Universities, and formally incorporated the education of the college students' associations into the "Top 10" education system with the support of the professional project. The introduction of these documents marks the more thorough understanding of the status and the role of the government and the community in the support of the professional projects. Second, the depth and breadth of the college students' community education are supported by the continuous extension of the professional project, and the construction of the university is more focused on the construction of the university. Under the support of the traditional professional project, the college students' association education in the form of the activity, the scope of the activity, the content of the subject is relatively single, the professional project supports the university student's community to educate the actual effect is not strong. In recent years, the country, the society and the school have carried on the top-level design of the students' association of the college students under the support of the professional project, gave a series of support, the activities of the university students gradually entered the system, the standardization construction, the professional project support the university student's community education scope and the depth to expand. The colleges and universities actively innovate and explore the new form and new connotation of the college students' association education under the support of the professional project ${ }^{[6]}$. 


\subsection{Professional project supports the gap between the education of the college students' associations and the requirements of the times}

With the support of professional projects, the educational work of college student associations has achieved some results, but there is still a certain gap compared with the requirements of the new era. (a). The practical content needs to be further enriched and deepened. Especially, the education and guidance of socialist core values, Chinese Dream and other mainstream values often stay on the surface, and are not sensitive to the sensitivity and sense of smell of political hotspots such as the National Congress of the Party and various meetings at the central level. There are problems of assimilation and formalization in the related activities carried out. (b). Under the support of the network specialty project, the degree of attention to the education of college student associations is insufficient. Contemporary college students are dependent on the network, and the network plays an increasing role in the education of college student associations with the support of professional projects because of its fast communication speed and timely convenience. At present, many colleges and universities do not give full play to the role of college student associations under the support of the professional projects of the network, and there is still room for deep excavation of the use of the network. (c). Under the support of professional projects, the joint force of educating students' associations in colleges and universities is insufficient, and it is difficult to play a synergistic role among the subjects of practice. Through social practice, voluntary service, innovation and entrepreneurship, colleges and universities carry out the education of college student associations supported by professional projects. Among them, the government, colleges and universities, society, enterprises and so on are the main body and participants in the education of college student associations supported by professional projects. The synergy of each practice subject needs to be improved, and an effective negotiation and participation mechanism has not yet been formed, which limits the play of the overall optimization function.

\section{COUNIERMEASURESTOPROMOTETHEEDUCATION OFCOLLEGESTUDENTASSOCIATIONSUNDERTHE SUPPORTOFPROFESSIONAL PROJECTS}

Under the background of the new era, the educational work of college student associations with the support of professional projects has achieved certain results, but there is a gap with the requirements of the times. Therefore, in order to adapt the educational work of university student associations to the development of the times under the support of professional projects, in addition to adhering to and improving the way of educating college student associations supported by traditional professional projects, it is also necessary to carry out and improve the way of educating students' associations in colleges and universities under the support of traditional professional projects. System and other aspects to improve the education of college student associations supported by professional projects of the times.

\subsection{Enrich the content of educating students' associations under the support of professional projects, and run through the theory of socialism with Chinese characteristics all the time}

(a). Focus on leading values. First, we should focus on the cultivation of the core values of socialism. A series of practical activities, make the core values truly in the ear, enter the brain, enter the heart, and constantly enhance the college students' identity to it. The cultivation and practice of the core values are integrated into all aspects of the college students' learning and life, and the effectiveness of the value education is improved. Second, it is necessary to strengthen the practice education of the great rejuvenation of Chinese dream of the Chinese nation, and integrate the ideal and belief education into the education work of the college students' associations under the support of the professional project. (b). To enrich and focus on the content of the students' community education in the support of the professional project. It is necessary to combine the theory education and the professional project with the education of the college students' associations. For Chinese colleges and universities, we should always use the theory of socialism with Chinese characteristics as the basic content, and serve as the guiding theory of the college students' community education with the support of the professional project. in addition, in that support of the professional project, the university student's community education work focuses on the hot issue of time and government, the education of the situation policy, make the practice activity follow the pulse of the times, let the university students feel the same breath and the common destiny with the nation and the nation in practice, and continuously cultivate their loyalty to the nation, the responsibility of the society and the feelings of the people.

\subsection{Time of the cultivation of students' associations in colleges and universities}

It is necessary to seize the new position of college student associations to educate people under the support of professional projects, and to give full play to the role of network platform to enhance the times of college student associations' education under the support of professional projects. It is also necessary to seize new positions, make full use of network platforms, and form a new pattern of online and offline collaborative education.

(a). By the construction of influential and credible network professional project support of college student associations education platform, the development of guidance, communication power of the website, WeChat official account, Weibo, client, etc., the establishment of new media professional project support college student associations education matrix, create a virtual practice platform, promote college student associations education cross-network, cross-platform under the support of professional projects. (b). Make the network become the service tool and medium for college student associations to educate people under the support of professional projects, make use of the network to carry out propaganda to the practice, expand the influence and appeal, give full play to the exemplary role of the practice example, and let more students participate fully in the practice. At the same time, let the network become a 
bridge between government departments, society, schools and students, which is more convenient for the educational work of college student associations to be carried out across regions with the support of professional projects.

\subsection{Promote the construction of a community for the education of college student associations with the support of professional projects}

In view of the problems such as the coordination between subjects and the formation of effective mechanism in the education of college student associations supported by professional projects, the Ministry of Education put forward for the first time in 2014 the goal of "building a community of education for college student associations supported by professional projects". The Ministry of Education and the Central Committee of the Communist Youth League put forward the implementation of the Construction Plan of the Community for the Education of College Student Associations with the support of professional projects, which puts forward new requirements for the education of college student associations supported by professional projects. With the support of professional projects, the educational community of college student associations is a combination of "all kinds of forces formed by strengthening and reforming practical teaching in colleges and universities and effectively promoting college students' social responsibility and practical ability to participate and play a role together. It is a combination of government, colleges and universities, enterprises, and all social forces to build together in accordance with the 'goal, mechanism, and resource sharing." Under the support of the professional project established by the principle of responsibility sharing, the educational carrier of college student associations is supported by the principle of responsibility sharing. To put it simply, it is to establish a university, government, society, enterprise and other forces to participate in the education of college student associations and play a synergistic role under the support of professional projects, so as to achieve the effect of " $1+1>2$ ".

\subsection{People-oriented, teaching according to their aptitude, promoting the individualized development of educational work of college student associations with the support of professional projects}

Contemporary college students have not only the group characteristics reflecting the characteristics of the times, but also the distinct characteristics as individuals. Therefore, to enhance the times of educating people by college student associations supported by professional projects, it is necessary to run through "people-oriented" and students as the starting point to carry out various practical activities according to the thought of teaching students according to their aptitude. First, according to the characteristics and differences of college students, the design is consistent with the actual situation of students, which can give full play to the practical contents and forms that students are good at, promote the individualized development of educational work of college students' associations under the support of professional projects, cultivate college students' interest in practical participation, enhance the degree of participation, so that each college student can find its own value from a variety of practical activities, so as to enhance the effect of educating people. Second, in the practical activity team, we should pay attention to the overall role of the team, give full play to each student's personality ability, cultivate their team consciousness and cooperation consciousness, so that the post-95 college students can strengthen the collective consciousness in the team activity. Through individualized design, it makes "no less" become a reality, promotes the education of college student associations to cover every college student under the support of professional projects, and promotes the growth and achievement of college students.

\section{CONCLUSIONS}

In short, in the new era of big change and big development, the improvement of the times is an urgent need to support the education of the college students' associations under the support of the professional project. As the cradle of the building of the socialist qualified builders and successors, the university should keep the pulse of the times and give full play to the actual effect of the students' community education in the support of the professional project, and promote the orderly development of the ideological and political work. At the same time, with the support of the professional project, the time nature of the college students' community education also needs the common participation of the government, the society, the enterprise and so on, and the maximum integration effect can be played.

\section{ACKNOWLEDGMENTS}

This project was supported by Study on Curriculum Refinement and Integrating Path of the Accounting Major in Higher Vocational Colleges-Based on New Apprenticeship, School-level Subject of Guangzhou Huashang Vocational College (kjy2019012)、Study on Project-Based Cross-discipline Integration Teaching Approach of the Tax Law in Higher Vocational Colleges Under New Circumstances of Interdisciplinary Subjects, Subject of Guangdong Society of Vocational and Technical Education

(201907Y50) 、 Research on the Targeting Cultivation Mode of Professional Societies in Higher Vocational Colleges: Collaboration of Industry and Education, Integration of Innovation and Professional Education, Link of Projects, Subject of Guangdong Tertiary Technical and Vocational Education Research Association (GDGZ19Y034)

\section{REFERENCES}

[1] LIN Ying, LI Tong, DU Lei. Exploration of innovative Design Curriculum Project-driven Teaching method [J]. Computer education,2015(9):72-74.

[2] ZHANG Jing, LEI Hongli. The role of college social activities on the socialization of college students[J]. 
[5] Zheng Bifang, Gu Xufei. Walk through the "Cloud"

Journal of Mudanjiang Education Institute,2018(3): 5153,68 .

[3] XUAN Hang. An Analysis of the role of Association organizations in ideological and political Education in Colleges and Universities [J]. Journal of Liaoning Radio and Television University,2014(04):17-19.

[4] XUE Jingying, NI Xiaoyong. On the Reform of College English Teaching under the trend of Educational Informatization[J]. Integration of Information Technology and Teaching practice, 2015(12): 43-45. end of practical Education Information--On the Application of Cloud platform in English Teaching[J]. Education and Teaching Forum 2016(03): 263-265.

[6] Zhang Yuzhen. Research on English learning strategies under the multimedia network environment $[\mathrm{J}]$. Chinese Language Journal (foreign language education and teaching), 2014, 09:92-93,95. 